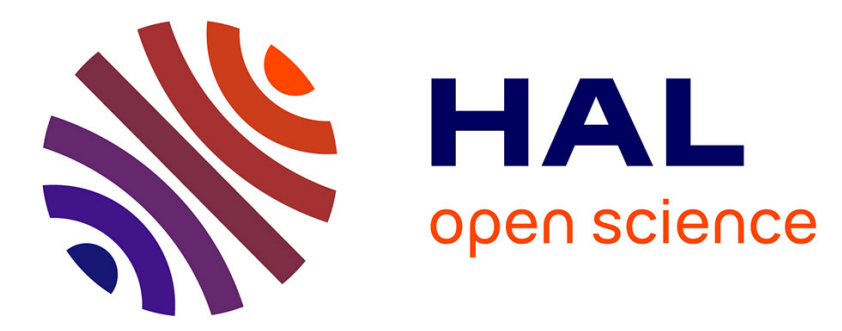

\title{
Transform continental margins - Part 1: Concepts and models
}

Christophe Basile

\section{To cite this version:}

Christophe Basile. Transform continental margins - Part 1: Concepts and models. Tectonophysics, 2015, 661, pp.1-10. 10.1016/j.tecto.2015.08.034 . hal-01261571

\section{HAL Id: hal-01261571 \\ https://hal.science/hal-01261571}

Submitted on 25 Jan 2016

HAL is a multi-disciplinary open access archive for the deposit and dissemination of scientific research documents, whether they are published or not. The documents may come from teaching and research institutions in France or abroad, or from public or private research centers.
L'archive ouverte pluridisciplinaire HAL, est destinée au dépôt et à la diffusion de documents scientifiques de niveau recherche, publiés ou non, émanant des établissements d'enseignement et de recherche français ou étrangers, des laboratoires publics ou privés. 


\title{
Transform continental margins - Part 1: Concepts and models
}

\author{
Christophe Basile
}

Address: Univ. Grenoble Alpes, CNRS, ISTerre, F-38041 Grenoble, France.cbasile@ujf-grenoble.

\begin{abstract}
This paper reviews the geodynamic concepts and models related to transform continental margins, and their implications on the structure of these margins. Simple kinematic models of transform faulting associated with continental rifting and oceanic accretion allow to define three successive stages of evolution, including intracontinental transform faulting, active transform margin, and passive transform margin. Each part of the transform margin experiences these three stages, but the evolution is diachronous along the margin. Both the duration of each stage and the cumulated strike-slip deformation increase from one extremity of the margin (inner corner) to the other (outer corner).

Initiation of transform faulting is related to the obliquity between the trend of the lithospheric deformed zone and the relative displacement of the lithospheric plates involved in divergence. In this oblique setting, alternating transform and divergent plate boundaries correspond to spatial partitioning of the deformation. Both obliquity and the timing of partitioning influence the shape of transform margins. Oblique margin can be defined when oblique rifting is followed by oblique oceanic accretion. In this case, no transform margin should exist in the prolongation of the oceanic fracture zones.

Vertical displacements along transform margins were mainly studied to explain the formation of marginal ridges. Numerous models were proposed, one of the most used is being based on thermal exchanges between the oceanic and the continental lithospheres across the transform fault. But this model is compatible neither with numerical computation including flexural behavior of the lithosphere nor with timing of vertical displacements and the lack of heating related to the passing of the oceanic accretion axis as recorded by the Côte d'IvoireGhana marginal ridge. Enhanced models are still needed. They should better take into account the erosion on the continental slope, and the level of coupling of the transform continental margin with the adjacent oceanic lithosphere.
\end{abstract}

\section{Keywords}

transform continental margin; sheared margin; strike-slip margin; transform fault; partitioning; oblique margin

\section{Introduction}

Transform continental margins first appeared as a scientific topic during the 1970's (Fail et al., 1970; Le Pichon and Hayes, 1971; Mascle, 1976a, 1976b; Rabinowitz and Labrecque, 1979; Scrutton, 1979), but since then they have only been sparsely studied, especially when compared with the other types (divergent or convergent) of continental margins. Regional case studies were mostly performed and published during the seventies and eighties (Agulhas: Scrutton, 1973 and 1976; Dingle, 1973; BenAvraham et al., 1997; Côte d'Ivoire-Ghana: Arens et al., 1971; Delteil et al., 1974; Blarez and Mascle, 1988; De Caprona, 1992; Basile et al., 1993; Exmouth Plateau: Lorenzo et al., 1991; Gulf of California: Bischoff and Henyey, 1974; Moore and Curray, 1982; Lonsdale, 1985; Newfoundland: Todd et al., 1988; Keen et al., 1990). Ocean Drilling
Program Leg 159 has been the only scientific drilling dedicated to a transform margin (Mascle et al., 1996 and 1997). Very few synthetic studies or reviews (Scrutton, 1979 and 1982; Mascle et al., 1987; Lorenzo, 1997; Reid and Jackson, 1997; Bird, 2001) were produced on this topic. The reasons why these margins were poorly studied can certainly be found in their complexity. These margins are not cylindrical at all (in their morphology, crustal structure or vertical displacements: for examples see Mercier de Lepinay et al., this volume), and their structure and evolution cannot be understood from a few cross-sections. But until the Jubilee discovery in 2007 offshore Ghana they also lacked of large hydrocarbon discoveries, and were not a priority target for oil industry. However, transform margins represent $16 \%$ of the cumulated length of continental margins (Mercier de Lepinay et al., this volume). The tectonic and sedimentary processes involved in their formation and evolution are specific and deserve scientific interest.

The goals of this paper are to present a review of the geodynamic concepts and models used to understand transform continental margins, including their initiation and vertical displacements. This paper is associated with that of Mercier de Lepinay et al. (this volume), which presents the first worldwide catalogue of transform margins and synthesizes the observations from regional case studies.

\section{Definition, historical perspective and terminology}

From a geodynamic point of view, a continental margin represents the transition zone between continental and oceanic lithospheres. The concept of transform continental margins came from the definition of 
transform faults (Wilson, 1965) as a 'new class of faults', where a lithospheric plate boundary is parallel to the relative plate displacement. Transform continental margins consequently refer to the juxtaposition, in the same location, of a continental margin with an active or previously active transform fault.

It is noteworthy that this terminology is based on the dynamics of the lithosphere, and not on geographic or physiographic characters. As a consequence, in this terminology a margin can be defined from the associated geodynamic process as transform, divergent or convergent A segment of margin then should be a part of a margin that can be defined by characteristics (structure, sedimentation, bathymetry) other than the geodynamic setting. For example, the northern side of the Gulf of Guinea contains several alternatively transform and divergent margins, such as, from West to East, the Liberia divergent margin, St Paul transform margin, Cape Palmas divergent margin, the Liberia-Côte d'Ivoire transform margin, the Ivorian divergent margin, and the Côte d'Ivoire-Ghana transform margin (Figure 1). Within the Côte d'Ivoire-Ghana margin, one can distinguish a western segment defined by a bathymetric marginal plateau, a central segment devoid of marginal plateau but sharing the same $\mathrm{N}^{\circ} 5^{\circ}$ trend for the continental slope, and an eastern segment with a $\mathrm{N} 40^{\circ}$-trending continental slope (Figure 1). A transform margin intersects a divergent margin, at its both ends. These intersections are named outer corner at the end of the margin located towards the oceanic accretion axis and inner corner at the opposite end, towards the continent (Figure 1).

Over the years, several different terms were used to describe transform continental margins: Wilson (1965) introduced the term 'transform fault', but it was first used in the oceanic domain. Fail et al. (1970) or Le Pichon and Hayes (1971) emphasized the extension of oceanic fracture zones along the trend of some segments of the continental margin. Mascle (1976a) first distinguished these segments as related to transform faulting, distinct from the Atlantic (riftrelated) and Pacific (subductionrelated) types. Following Keen and Keen (1973), Mascle (1976a) defined this third continental margin type as 'transform faulted or strike-slip margin'. Since then, the terms 'strike-slip margin' (e.g. Nagel et al., 1986), 'shear margin' (Rabinowitz and Labrecque, 1979; Scrutton, 1979) and 'transform margin' (Lonsdale, 1985; Mascle and Blarez, 1987) have been used.

Among these terms, 'transform margin' appears to be the most relevant to link these margins to the processes that controlled their formation. Although 'strike-slip' correctly describes the displacement that occurred along these margins, it is not linked to any specific scale, such as upper crustal, crustal or lithospheric, whereas 'transform' implies a lithospheric scale (Freund, 1974). 'Shear' should be avoided in description of these margins, because shearing is the main tectonic process involved in the development of all margin settings, with various geometries (strikeslip, dip-slip, normal or reverse, in steep or flat shear zones). For transform margins, the adjective 'shear' reflects horizontal shear along vertical faults. Therefore, 'transform margin' should be used to name the continent-ocean transition derived from a transform plate boundary.

Another terminology has also been comprehensively used. It was primarily based on the geographic location (Atlantic- versus Pacifictype margins), then on the lithospheric plate boundary character, including passive versus active margins. The formers result from divergent movements but are located within a lithospheric plate

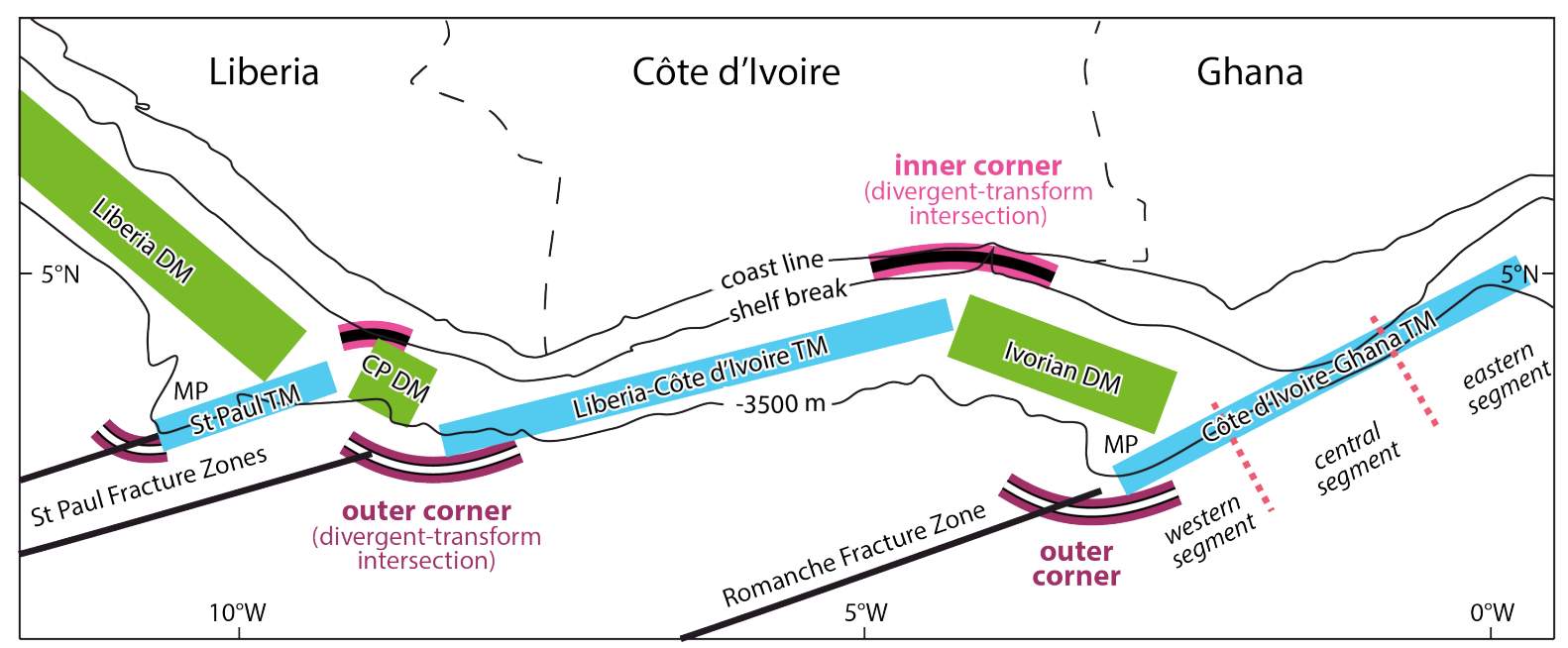

Figure 1: Geodynamic map of the northern side of the Gulf of Guinea. MP: Marginal Plateau; TM: Transform Margin; DM: Divergent Margin; CP DM: Cape Palmas Divergent Margin. The trends of margins are drawn from the bathymetry only, and do not reflect the continent-ocean boundary. 
(intra-plate), while the latters result from convergent movements at lithospheric plate boundaries.

Transform margins were first described in the Equatorial Atlantic Ocean, where they are actually located intra-plate. They were consequently referred to as a specific class of Atlantic-type or passive margins (Mascle, 1976a). In a divergent margin the displacement at plate boundary (active stage) is restricted to a previous intra-continental (rift) stage, and the continent-ocean transition is tectonically inactive (intra-plate) at the margin stage. However, as explained in the next section, a transform margin experiences several stages of evolution, one of them being a tectonically active plate boundary. For example, some transform margins are seismically active, such as those in the Gulf of California (Goff et al., 1987) or those of the Cayman trough (Leroy et al., 2000). Consequently, the Atlantic/Pacific and passive/active terminology that predated the identification of transform margins is clearly inadequate.

\section{A kinematic model for transform continental margins}

The kinematic evolution of a transform margin can be divided into three stages (Mascle and Blarez, 1987), which are defined by the position of the active transform fault and the nature of the lithosphere on its sides, including: 1) intra-continental transform fault, 2) active transform margin, and 3) passive transform margin (Figure 2).

A specific point on the future transform margin (blue star in Figure 2) first experiences intracontinental transform faulting (Figure 2-1 to 2-3), which ends with its movement against a stretched continental lithosphere (Figure 2-3). It is noteworthy that the syn-rift transform fault does not limit the edge of the rift. The transform fault is characterized, along its entire length, by a constant relative displacement between the two plates (Freund, 1974), and 'terminates abruptly at both ends' (Wilson, 1965). At the edge of a rifted area, the relative displacement decreases from one side of the rift to the other. Horsetail splays typically accommodate this progressive change of relative displacement and the connection with rifted structures (Christie-Blick and Biddle, 1985, Basile et al., 1993).

During the intra-continental transform stage, the syn-rift transform fault connects the corners of individual rifts (Figure 2-1), while the post-rift transform fault connects the incipient oceanic accretion axes within the rifts (Figure 2-2). Consequently, the post-rift transform fault is longer than the syn-rift one, by propagation in the outer corner.

During the active transform margin stage, the continental lithosphere slides against the oceanic lithosphere, defining an active transform margin (Figures 2-4 to 2-6 for the blue star). This stage ends when the oceanic accretion axis passes along the transform margin (Figure 2-6 for the blue star). Then starts the passive transform margin stage (Figure 2-7 to 2-9 for the blue star). The first two stages are tectonically active and correspond to an active transform plate boundary. During the third and last stage, the transform margin is intra-plate.

The comparison of various locations along the transform margin (blue, purple or red stars in Figure 2) shows that the described three stages are not coeval along the margin. For example the purple star ends its active transform margin stage in Figure 2-3, while the blue and red stars are still within the intracontinental transform stage. In Figure 2-4, the red star experiences the intra-continental transform stage, the blue star the active transform margin stage, and the purple one the passive transform margin stage.

The timing of these three stages depends on the location along the transform margin: the closer the margin segment to the inner corner, the briefer intracontinental transform faulting and active transform margin stages are. Both intra-continental transform and active transform margin stages last the time $\mathrm{t}=\mathrm{d}_{\mathrm{in}} / \mathrm{SR}$ after the start of oceanic accretion, where $d_{\text {in }}$ is the distance between the given point and the continentocean boundary in the inner corner, and SR is the oceanic spreading rate (Figures 2 and 3). The spreading rate SR may present temporal variations for very long transform faults, but can be considered as a constant for most transform margins where the active stage duration was shorter than 10 My (Mercier de Lepinay et al., this volume). This time also equals to $\left(\mathrm{L}-\mathrm{d}_{\mathrm{ou}}\right) / \mathrm{SR}$, where $\mathrm{L}$ is the length of the transform margin between the continent-ocean boundaries at inner and outer corners, while $\mathrm{d}_{\mathrm{ou}}$ is the distance between the given point and the continent-ocean boundary at the outer corner (Figures 2 and 3). If transform faulting predates the oceanic accretion, then the duration of the intra-continental transform stage increases by the duration of rifting.

The last contact between the two continental lithospheres is lost when the intra-continental transform stage ends at the extremity of the transform margin (continent-ocean boundary at the outer corner, Figure 3). This last contact occurs at the time $\mathrm{t}=\mathrm{L} / \mathrm{SR}$ after the start of the oceanic accretion. Along a continent, the lengths of the transform margins can be highly variable in a same area (e.g. Figure 1) and the last continental lithosphere contact occurs at the extremity of the longest transform margin. The last contact between the two continental lithospheres also marks the starting time for the intra-oceanic transform faulting, and the connection of deep oceanic basins. However, the connection of surface marine waters is expected to have occurred a bit earlier, when the 

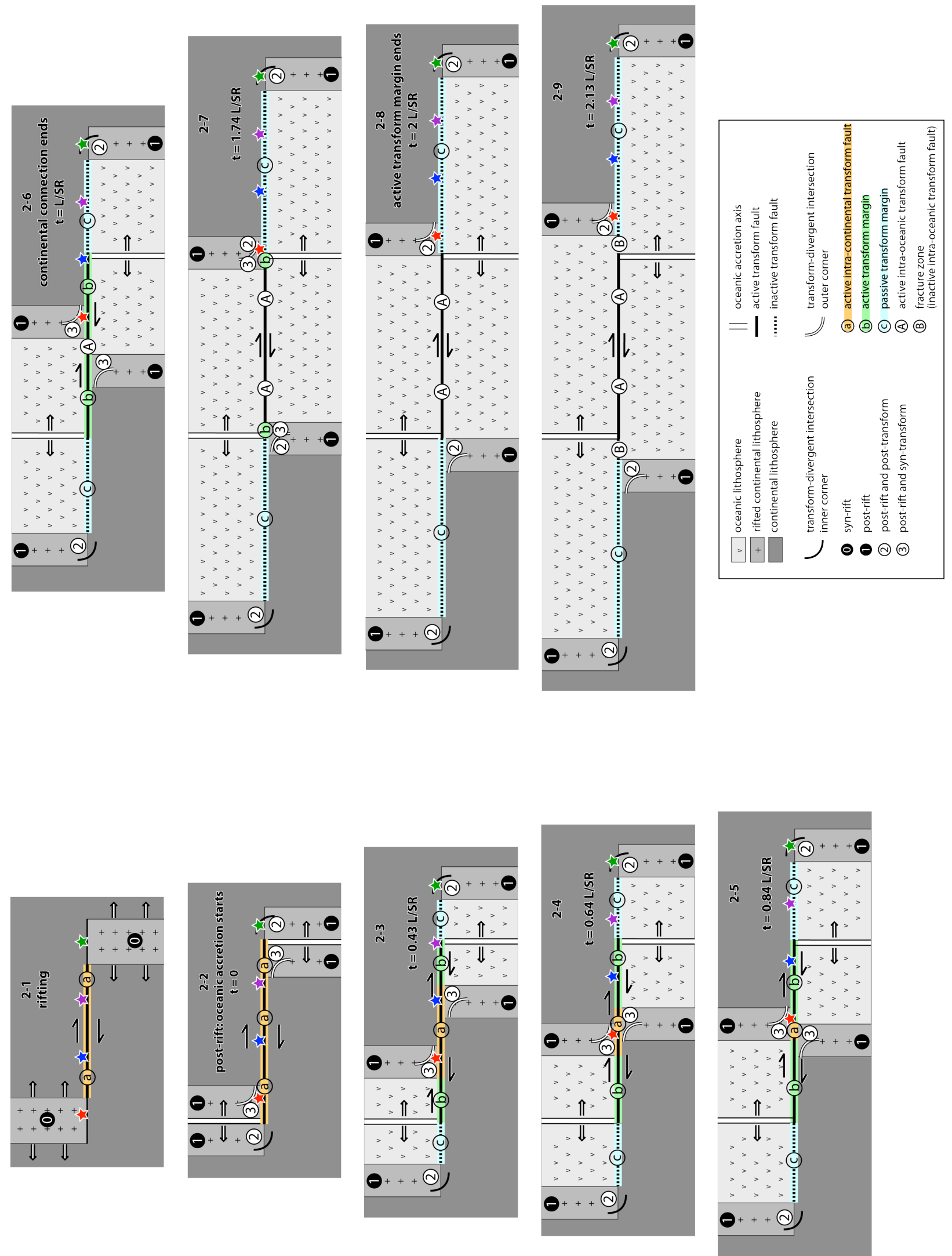

Figure 2: Schematic evolution of a transform margin and adjacent divergent margins, modified from Le Pichon and Hayes (1971), Scrutton (1979), Mascle and Blarez (1987) and Basile et al. (2013). Timing is given as a function of the ratio between the active transform fault length ( $L$, equals the accretion axis offset) and the spreading rate (SR). This sketch assumes inherited plate boundaries, constant displacement rates, and excludes oblique displacements, as opposed to the scenario shown in Figure 6. It also neglects the sphericitv of Earth. where plate boundaries are arcs of circles. See text for further explanations. 
two divergent margins moved along each other (Figure 2-4).

The passive transform margin stage starts at time $\mathrm{t}=2 \mathrm{~d}_{\text {in }} / \mathrm{SR}$ ( or $\mathrm{t}$ $\left.=2\left(\mathrm{~L}-\mathrm{d}_{\mathrm{ou}}\right) / \mathrm{SR}\right)$ after the beginning of oceanic accretion. The beginning of this stage should be recorded by the post-transform unconformity, which is diachronous along the transform margin, and postdates the post-rift unconformity at the outer corner transform-divergent intersection (Figure 3).

The described schematic evolution implies along-strike asymmetry of the transform margin. Each part of the transform margin experiences the three same stages, but the duration of each stage increases from the inner to the outer corners. This results in diachronic evolution.

Moreover, the two rift-transform intersections have very different behavior. The inner corner (green star in Figures 2 and 3) is not affected by the transform fault itself, but only by the transfer structures such as horsetail structures that connect strike-slip

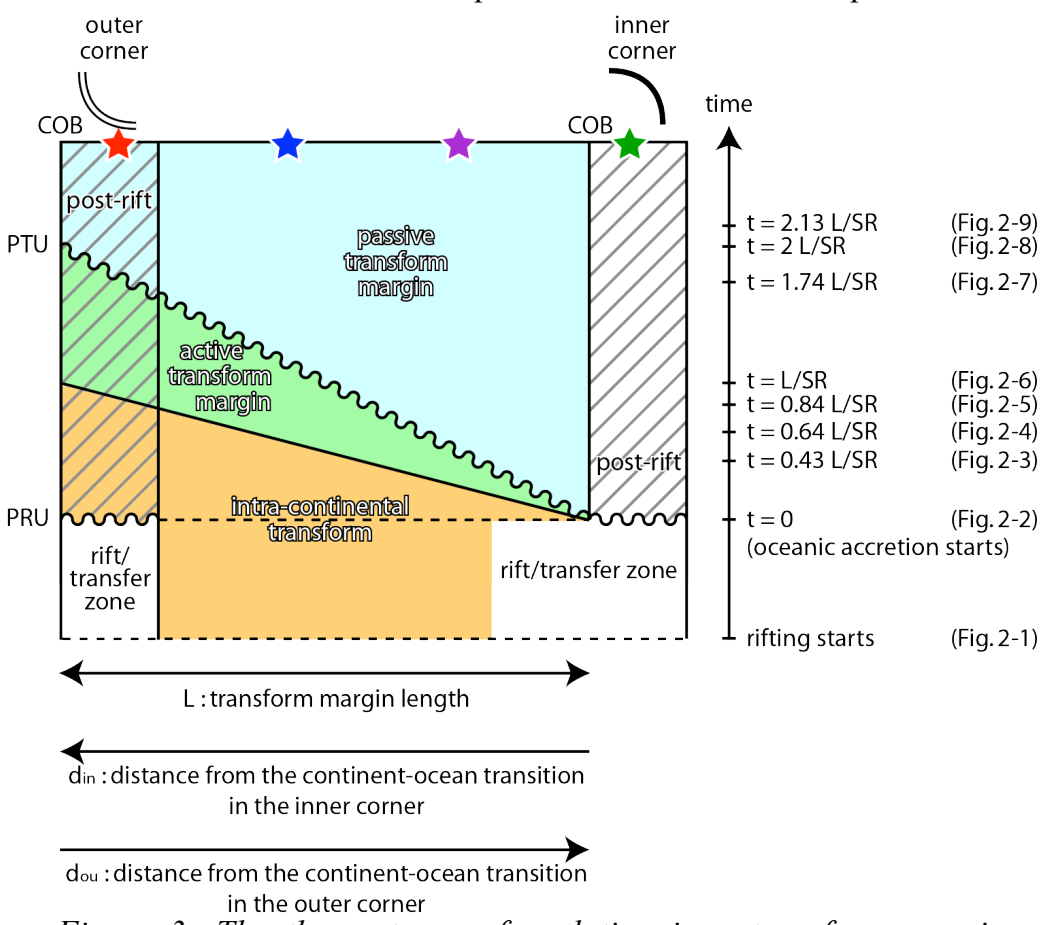

Figure 3: The three stages of evolution in a transform margin, depending on time and location along strike. The red, blue, purple and green stars are located along transform margin strike in Figure 2. SR: Spreading Rate; PRU: Post-Rift Unconformity; PTU: PostTransform Unconformity; COB: Continent-Ocean Boundary. See text for comments.

and normal faults at the tip of the intra-continental rift zone (Figures 2-1 and 3). In fact, the inner corner does not belong to the transform margin itself, and records only the post-rift unconformity (Figure 3). On the contrary, the outer corner (red star in Figures 2 and 3) is the part of the transform margin that experiences the longest transform fault activity after the end of rifting. The outer corner also contains a transfer zone active during the rifting, which was cut by the transform fault after the rifting. Here, both post-rift and post-transform unconformities are expected to occur and should be clearly separate (Figure 3).

\section{Initiation of transform margins}

Initiation of transform continental margins remains an open question. Most of the early studies assumed that transform faults re-activate older continental structures, providing some examples of onshore tectonic structures lined up with or

(n)

(n)

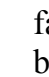
from the geometry of the continental break-up, to their postrift formation during the oceanic spreading.

\section{Deformation partitioning in divergent setting}

It is possible to look at the debate about the transform margin initiation from another point of view, changing the investigation scale from a single plate boundary situation to regional scale situation. In the oceanic lithosphere, alternating transform faults and spreading axes accommodate the obliquity between the direction of relative plate displacement and the regional plate boundary strike (Figure 4A). Some slow to very slow spreading axis, such as the Mohns and Reykjanes ridges in the northern Atlantic, are devoid of transform faults (Dauteuil and Brun, 1996; Peyve 2009). With 
these few exceptions, where oceanic accretion is oblique relatively to the plate displacement, the deformation of the oceanic lithosphere is commonly accommodated by plate boundaries either parallel (spreading axis) or perpendicular (transform fault) to the relative plate displacement.

Partitioning of deformation at plate boundaries is well described for convergent settings (Fitch, 1972), where oblique convergence is accommodated by strike-slip faulting within the volcanic arc and by frontal convergence at the trench. Similarly, oblique divergence is accommodated in the oceanic lithosphere by spatial partitioning of the deformation (Figure 4A).

In intra-continental divergent setting, relative displacements

4A: oceanic lithosphere
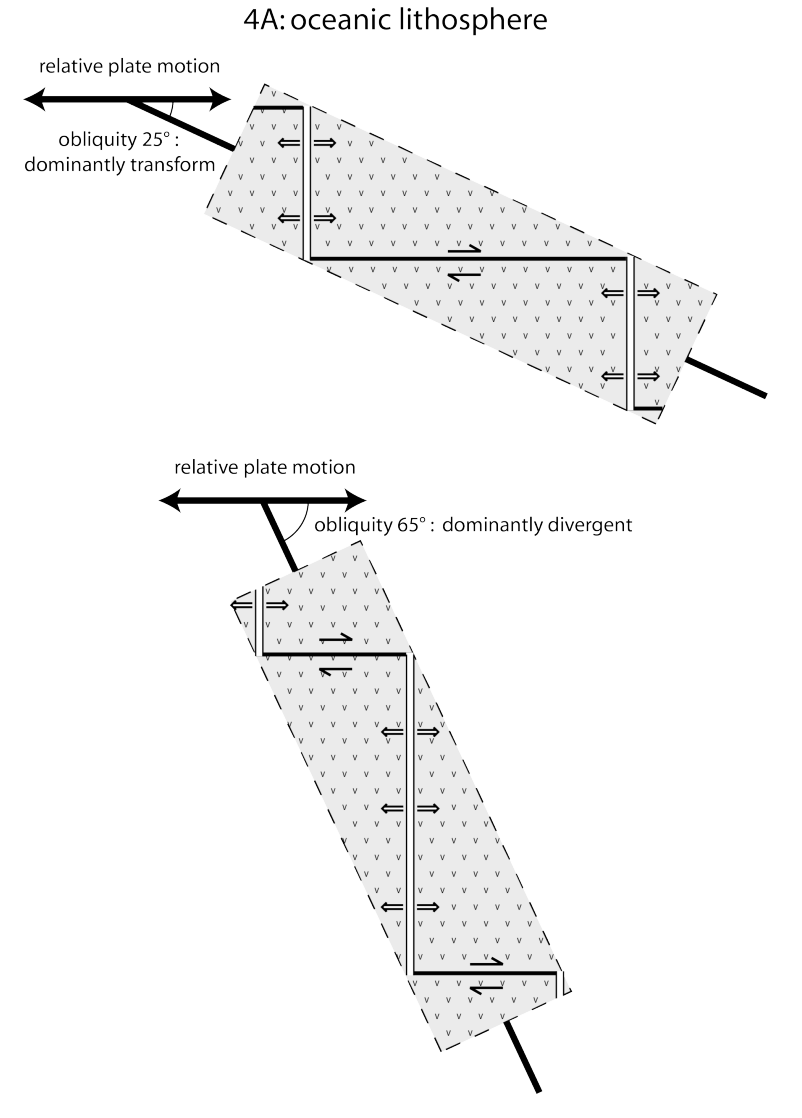

between rift segments are mainly accommodated by transfer fault zones (Gibbs, 1984; Milani and Davison, 1988), in some cases referred to as transform faults (Chorowicz, 1989). However, for the East African Rift, these transfer structures are oblique to the relative plate displacement (Rosendahl, 1987; Versfelt and Rosendahl, 1989; Bird, 2003), and partitioning does not appear to be efficient in this setting. As suggested by Dauteuil and Brun (1996), the mechanical layering of the lithosphere may be involved, and partitioning may be associated with highly localized deformation. A very weak lithosphere, such as the oceanic one close to the accretion axis, should allow this localisation. The existence of long intra-continental transform faults, like the Dead Sea transform or the
Cerro Prieto transform in the northern part of the Gulf of California, shows that transform faulting can also occur in intracontinental setting.

From these observations it appears that divergent partitioning, while obvious in the oceanic domains, does not always occur during continental rifting. Accordingly, several theoretical cases can be considered (Figures 4 and 5):

a) Transform faults can predate oceanic accretion. This case should be more frequent for low angles between the regional trend and the relative plate motion, in which case the length of transform faults exceeds both the length and width of individual rifts (Figure 4B). But it can also occur in the case of narrow rifts with no overlap at their tips (Figure 5-1A).


Figure 4: Obliquity between relative plate motion and the regional trend of a divergent plate boundary (intra-oceanic: 4A; intra-continental: $4 B$ ). The regional trend is defined from the alignment of homologous structures, such as the transform/accretion axis intersection (4A), or the edges of rifted basins (4B). $0^{\circ}$ obliquity is a pure transform fault, $90^{\circ}$ obliquity a pure divergent plate boundary. Same symbols as in Figure 2. Note that because the divergent plate boundary is narrower in the oceanic lithosphere (4A) than in the continental one (4B), the intra-oceanic transform fault is longer than the syn-rift intra-continental one for the same obliquity. See text for further comments. 
b) Continental rifting can evolve without any transform fault. In this case, the obliquity between the regional trend of the rift and the relative plate displacement is accommodated either by oblique rifting (Figure 6-1) or by overlapping en echelon rift segments when the width of individual rifts exceeds the offset with the adjacent rift segment (Figure 5-1B). In this last setting, transfer zones separate rift segments and both inner and outer corners are deformed within these transfer zones by strike-slip or transtensional faulting, with strike slip increasing from the inner to 5-1: rifting
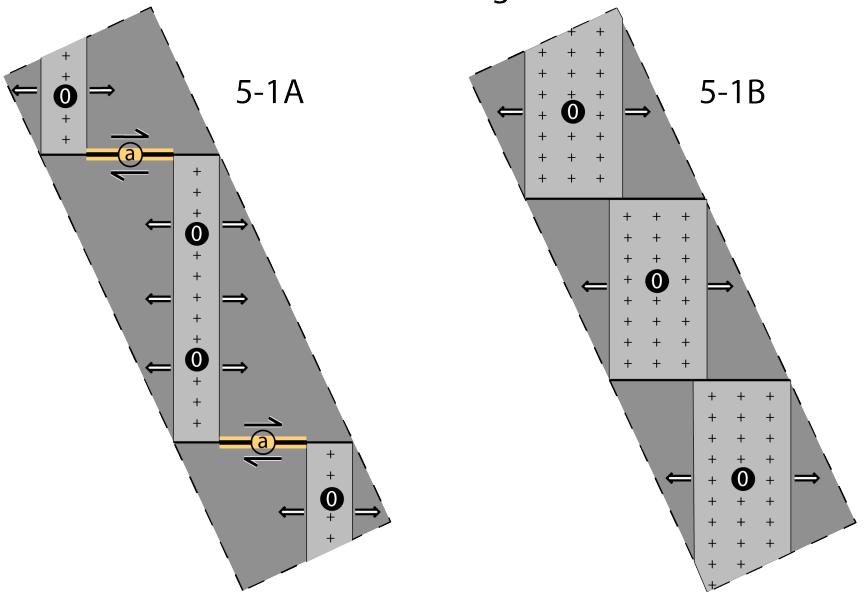

he outer corner.

In these two models, transform faults may appear at the start of oceanic accretion in the prolongation of transfer zones (Figure 5-2B) or within the most oblique parts (Figure 6-2A). In the case of oblique rifting, these transform faults define transform margins that postdate oblique rifting (Figures 6-3A and 6-4A), with strike-slip faulting crosscutting the normal or transtensional faults developed during the oblique rifting. This also induces an asymmetry between a narrow inner corner and a wide outer corner, where large 


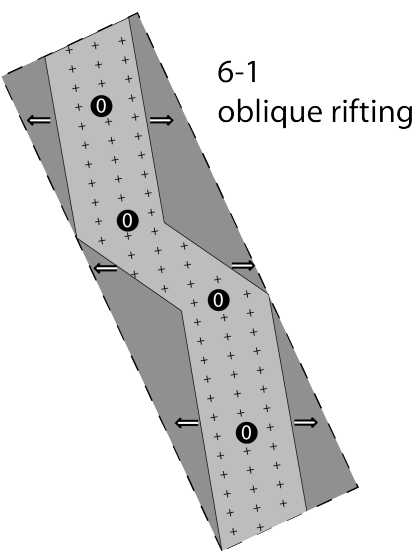

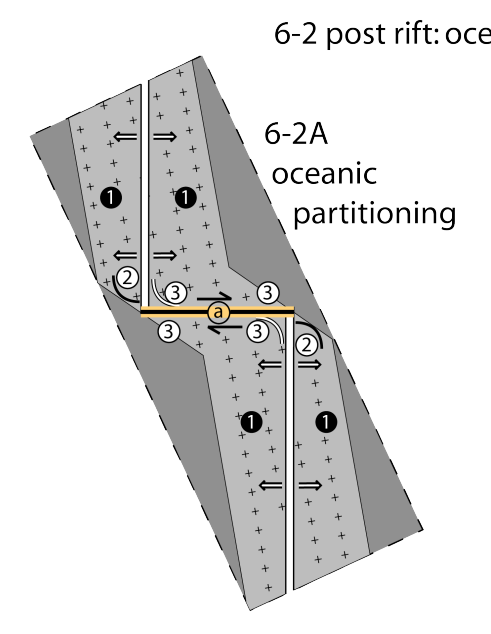

accretion starts
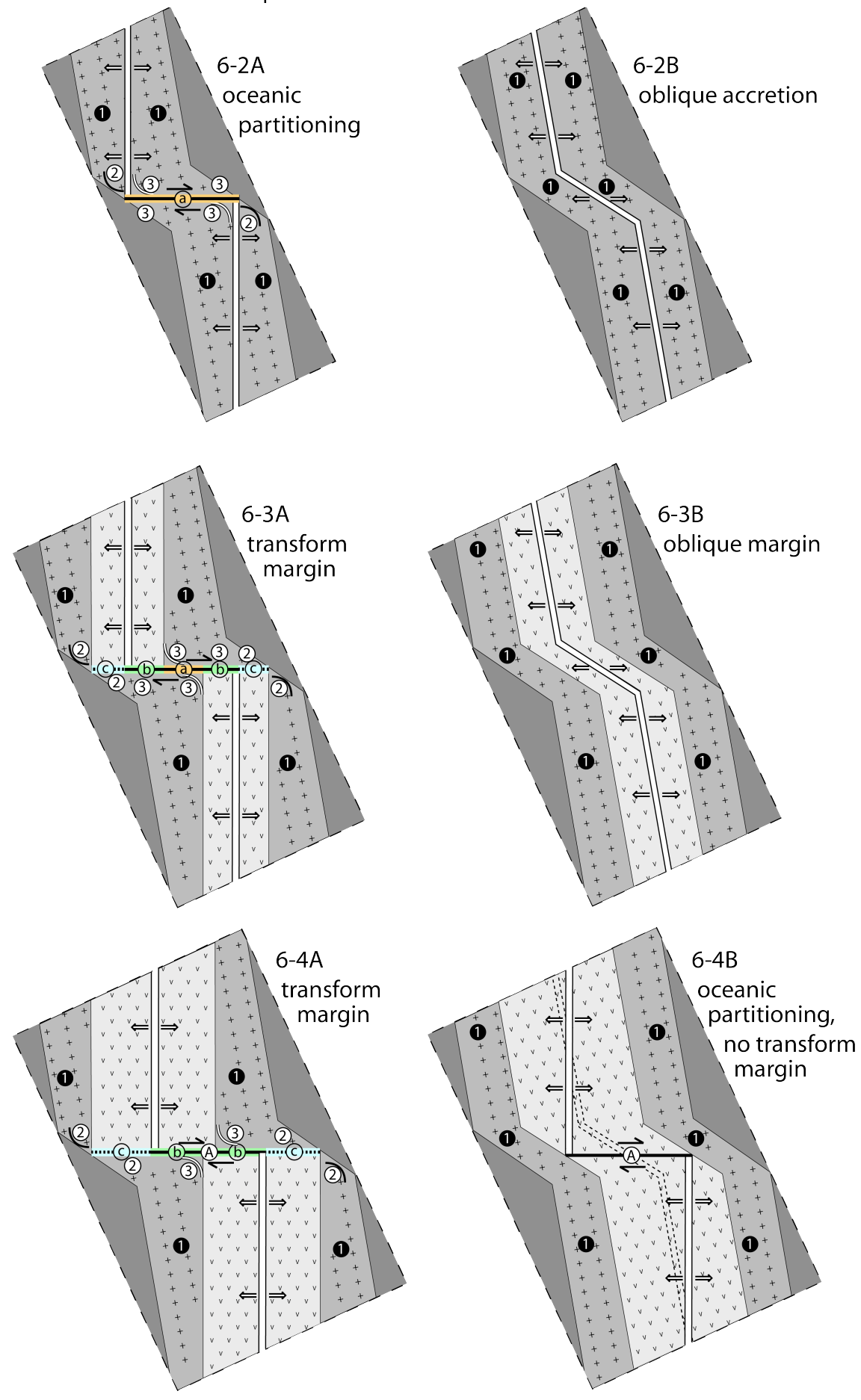

Figure 6: Oblique rifting and influence of the timing of deformation partitioning, either when oceanic accretion starts (Figure 6-2A to 6-4A) or after the beginning of oceanic accretion (Figure 6-2B to 6$4 B)$. The obliquity between the regional trend and the relative plate displacement $\left(65^{\circ}\right)$ is the same as in Figure 5. Same symbols as in Figure 2. The dotted line in Figure 6-4B represents the position of the oceanic accretion axis prior to the onset of partitioning. The new oceanic accretion axis probably does not appear everywhere simultaneously, but probably results from rift propagation. See text for comments. 


\section{Models for vertical displacements}

One of the most striking characteristic features of transform margins is a frequent occurrence of a marginal ridge, parallel to the transform fault, at the outer corner of the transform margin, i.e. where the transform margin experienced the maximum duration of strikeslip deformation. One of the best examples and best-studied site is the marginal ridge of the Côte d'Ivoire-Ghana transform margin (Basile et al., 1993; Basile et al., 1996 and references herein; Mascle et al., 1997; Basile et al., 1998) (Figure 7A). Other examples of marginal ridge are shown and discussed in Mercier de Lepinay et al., this volume.

Many models were proposed to explain the development of marginal ridges. The first group of models is related to the crustal thickness variations. Le Pichon and Hayes (1971) proposed that a marginal ridge is a continental sliver, transported within the transform fault from a place with relatively thick continental crust towards a rifted basin where the adjacent crust is thinned and therefore deeper (Figure 7C). Some authors (Huguen et al., 2001; Attoh et al., 2004) proposed a related explanation, where the marginal ridge results from crustal thickening by transpression in the intra-continental transform zone (Figure 7B). These models imply a crustal root below the marginal ridge. There is only one described case where the crustal thickening can be associated with marginal ridge. It is the southern transform boundary of the Exmouth Plateau, where a wide marginal ridge is associated with magmatic underplating at depth (Lorenzo et al., 1991). However, mapping of the Moho depth by wide angle seismic evidences a flat and horizontal Moho below the marginal ridges in most examples (e.g. Sage et al., 2000) (Figure 7A).

The second group of models is associated with the lateral heat transfer from the oceanic lithosphere to the continental one across the transform fault. The contact of the oceanic lithosphere against the continental one across the transform margin produces a horizontal thermal gradient, which results in the continental lithosphere being heated by the oceanic one. This heating reduces the thickness of the continental lithosphere, and induces a thermal uplift. The subsequent cooling of the lithosphere results in thermal subsidence.

This thermal uplift is supposed to be at its maximum when the hottest oceanic lithosphere, i.e. the spreading axis, moves along the transform margin. Scrutton (1979) first proposed this mechanism, which was also supported by Mascle and Blarez (1987), and modeled by Todd and Keen (1989) and Lorenzo and Vera (1992) for Newfoundland and Exmouth margins, respectively. Reid (1989) and Vågnes (1997) also proposed thermo-mechanical models of the uplift associated with lithospheric ductile flow along the transform fault, and inducing uplift close to the plate boundary at the time of oceanic accretion.

However, these thermomechanical models were all based on constant heating by the oceanic lithosphere, i.e. they did not take into account the cooling of the oceanic lithosphere by the continental one. Furthermore they cannot explain the stability of the marginal ridges through time, which remain elevated several tens of million years after the transform margin became inactive, despite of the fact that the thermal subsidence should have erased the syn-transform thermal effects. Nemčok et al. (2012) also suggested that heat transfer alone induces a maximum uplift limited to few hundred meters, which cannot fit the observations

Finally, Gadd and Scrutton (1997) discussed the validity of the thermal uplift models. As previous studies (Todd and Keen, 1989; Lorenzo and Vera, 1992), they showed that the uplift generated by heat transfer from the oceanic to the continental lithosphere decreases from the transform fault towards the continent. Assuming local isostasy, the maximum uplift computed at the time of the oceanic accretion at the foot of the transform margin can fit the observed shape and elevation of a marginal ridge. This is not the case when regional isostasy is assumed. Then, the maximum uplift can reach only few hundred meters (Figure 7E). In both cases, subsequent thermal subsidence reduces the uplift to few tens to few hundred meters, and cannot fit the observed marginal ridges.

Ocean Drilling Program (ODP) Leg 159 was designed (among other topics) to test the heattransfer model by investigating the vertical displacements through time and space along the Côte d'Ivoire-Ghana transform margin (Mascle et al., 1996). It indicated that no thermal event was associated with the passing of the oceanic accretion axis along the transform margin (Wagner and Pletsch, 2001), and that the vertical displacements are not correlated with this passing, because the uplift of the ridge was interpreted as starting earlier during the intra-continental stage (Basile et al., 1998).

The third group of models that explain the morphology and vertical displacements of the marginal ridge is based on the flexural response of the lithosphere to unloading by erosion along the transform fault (Basile and Allemand, 2002) (Figure 7D). The driving mechanism is the difference in elevation between the two adjacent lithospheres across the transform margin. It induces the erosion of the edge of the continental plate, which is higher. When the active transform fault acts as a free border for vertical displacements, this erosion discharges the edge of the plate and allows for a flexural uplift similar in shape to a rift shoulder. Both the flexural shape (Basile 


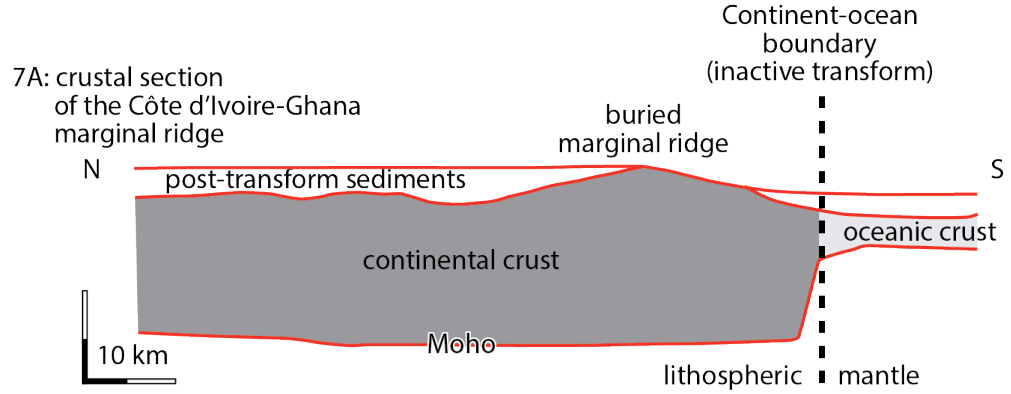

7B: crustal thickening by transpression
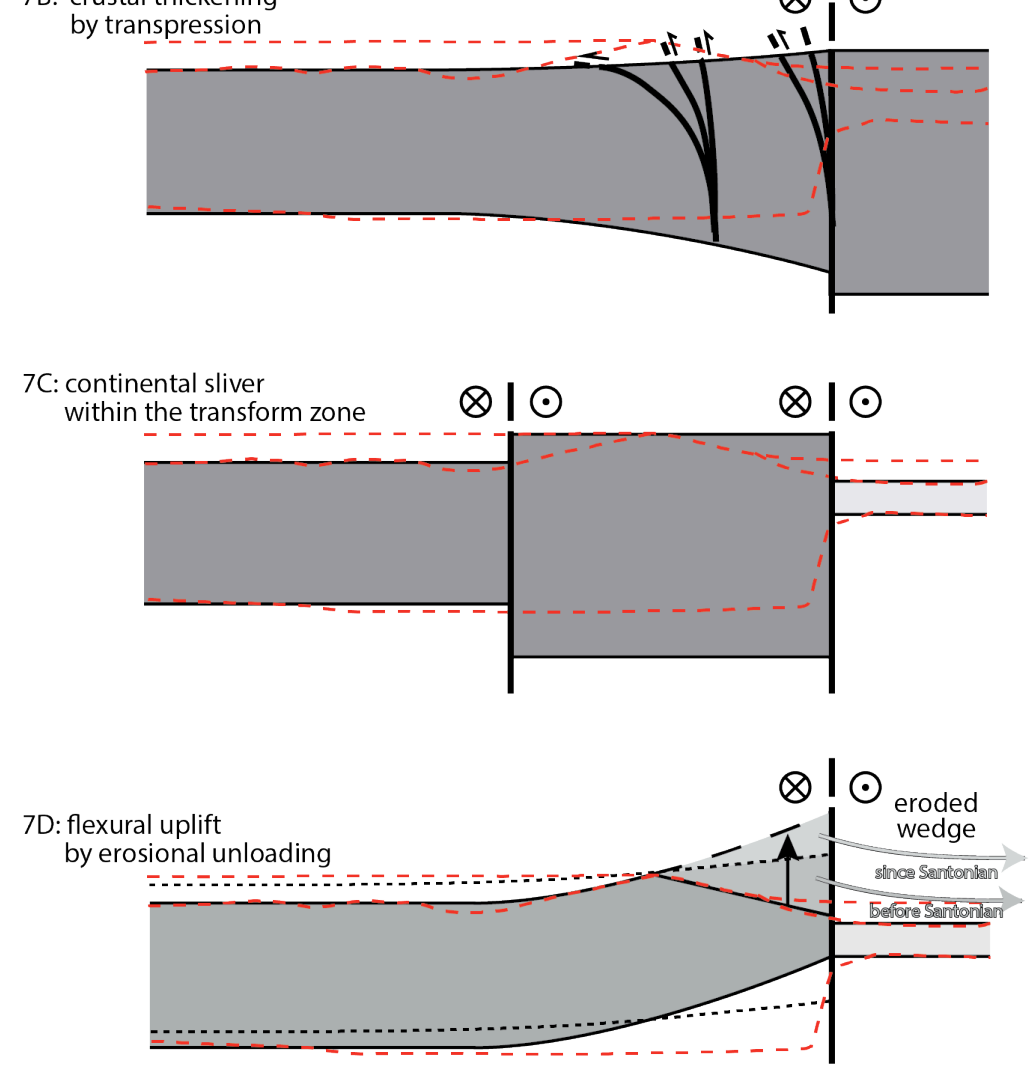

7E: thermal uplift
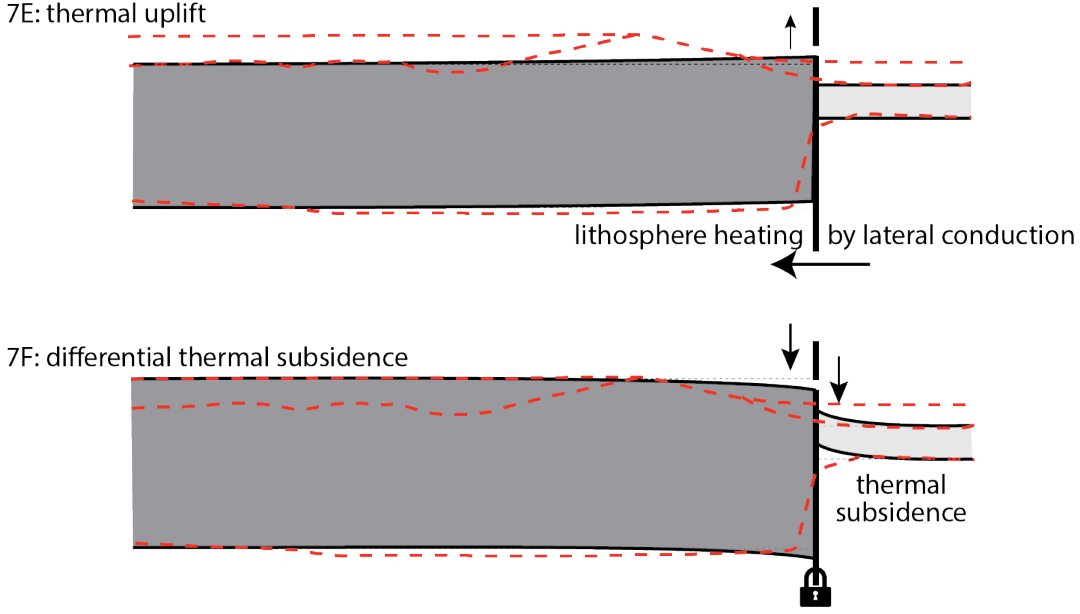

Figure 7: Conceptual and numerical models explaining the marginal ridge and vertical displacements along transform continental margins. All sections are displayed with no vertical exaggeration, and are superposed to the crustal section of the Côte d'IvoireGhana marginal ridge ( $7 \mathrm{~A}$, from Sage et al., 1997) (red dotted lines). Figure $7 B$ is modified from Huguen et al., 2001. In Figure 7D, the black dotted line represents the shape of the marginal ridge restored at Santonian times, and fitted by the flexural uplift of the continental border (Basile and Allemand, 2002). The present day shape results from the loading by the sedimentary infilling in the deep Ivorian basin north of the marginal ridge and unloading by erosion of the continental slope. The continental and oceanic lithospheres are supposed to be decoupled before Santonian (active transform fault), coupled since then (passive transform margin). Figure $7 E$ displays the flexural uplift induced by thermal conduction, as computed by Gadd and Scrutton, 1997. The thin dotted line indicates the horizontal for reference. Figure $7 F$ shows the downward flexure of the transform margin coupled (padlock) across the inactive transform fault with the thermally subsiding oceanic lithosphere (inspired from Lorenzo and Wessel, 1997). 
and Allemand, 2002; ten Brink et al., 1997; Vågnes, 1997), and the timing of uplift and erosion of the marginal ridge (Basile et al., 1998; Bigot-Cormier et al., 2005) support this flexural model. However, the shape of the Moho does not show the uplift that should be induced by the flexural bending (Figure 7D).

However, a systematic study of vertical displacements is still lacking for transform margins, and the bathymetric shape can be a useful tool for it (Mercier de Lepinay et al., this volume). As the continental lithosphere is not thinned or poorly thinned along transform margins, thermal subsidence is not expected to occur. But the continental lithosphere is in contact with the oceanic lithosphere, and even if heat transfer is not efficient, the vertical displacements of the margin should be strongly controlled by the coupling or decoupling of the two plates across the transform fault. As discussed above, flexural uplift can be related to decoupled plates across the transform fault, expected when the transform fault is active (Basile and Allemand, 2002). On the other hand, flexural subsidence may result from coupled plates (more likely in the passive margin stage) and lead to downward flexure of the continental edge driven by the thermal subsidence and sedimentary loading of the adjacent oceanic plate (Lorenzo and Wessel, 1997) (Figure 7F).

\section{Conclusion}

The concept of transform margin emerged from the prolongation of oceanic transform faults towards the continental margins (Le Pichon and Hayes, 1971; Mascle 1976a). The kinematic of transform margins has been similarly derived from the kinematic of oceanic transform faults (Le Pichon and Hayes, 1971; Scrutton, 1979; Mascle and Blarez, 1987), using the assumption that inherited tectonic features localize the incipient transform faults. However, this inheritance hypothesis appears questionable, and an alternative approach can be proposed, based on the partitioning of deformation between divergent and transform plate boundaries. It implies a variability of the kinematic evolution that is controlled by variations in both geometry and timing of partitioning. In any case, these kinematic models as the models proposed for the vertical displacements along transform margins are based on very few natural case studies, while the exhaustive investigation of Mercier de Lepinay et al. (this volume) identified 79 transform margins worldwide. It provides new insights for the morphology of transform margins and their geodynamic setting (Mercier de Lepinay et al., this volume), and can be a guideline for new investigations on transform margins.

\section{Acknowledgments}

This work has been supported by CNRS/INSU Action Marge program, and by Labex OSUG@2020(ANR10LABX56). I am particularly indebted to $M$. Mercier de Lépinay and my colleagues L. Loncke, A. Maillard, M. Patriat and W. Roest for their help and comments at various stages of this work, and to two anonymous reviewers and G. Iaffaldano who contributed to improve this paper. I also thank the other participants of IGUANES cruise who pushed me to publish this work, and the participants of Action Marge workshops for the fruitful discussions we had.

\section{References}

Arens, G., Delteil, J.R., Valery, P., Damotte, B., Montadert, L., Patriat, P., 1971. The continental margin of the Ivory Coast and Ghana. In: The geology of the East Atlantic continental margin, Delany F.M. (Ed.), Rep. 70/16, 4, Africa. Inst. Geol. Sci. London, 61-78.

Attoh, K., Brown, L., Guo J., Heanlein, J., 2004. Seismic stratigraphic record of transpression and uplift on the Romanche transform margin, offshore Ghana. Tectonophysics, 378, 1-16.

Basile, C., and Allemand, P., 2002. Erosion and flexural uplift along transform faults. Geophys. J. Int., 151, 646-653.

Basile, C., Maillard A., Patriat M., Gaullier V., Loncke, L., Roest, W., Mercier de Lepinay, M., Pattier, F., 2013. Structure and evolution of the Demerara Plateau, offshore French Guiana : rifting, tectonic inversion and post-rift tilting at transform-divergent margins intersection. Tectonophysics, 591, 16-29. Doi: 10.1016/j.tecto.2012.01.010
Basile, C., Mascle, J., Benkhelil, J., Bouillin, J.P., 1998. Geodynamic evolution of the Cote d'Ivoire-Ghana transform margin: an overview of Leg 159 results. In Mascle, J., Lohmann, G.P., Clift, P.D., eds, Proc. ODP Sci. Res., 159, p. 101-110.

Basile, C., Mascle, J., Guiraud, R., 2005. Phanerozoic geological evolution of the Equatorial Atlantic domain. J. Afric. Earth Sci., 43, 275-282.

Basile, C., Mascle, J., Popoff, M., Bouillin, J.P., Mascle, G., 1993. The Côte d'Ivoire-Ghana transform margin: a marginal ridge structure deduced from seismic data. Tectonophysics, 222, 1-19.

Basile, C., Mascle, J., Sage, F., Lamarche, G., Pontoise, B., 1996. Pre-cruise and site surveys: a synthesis of marine geological and geophysical data on the Côte d'Ivoire-Ghana transform margin. In Mascle, J., Lohmann, G.P., Clift, P.D., eds, Proc. ODP Init. Rep., 159, 4760. 
Bellahsen, N., Leroy, S., Autin, J., Razin, P., d'Acremont, E., Sloan, H., Pik, R., Ahmed, A., Khanbari, K., 2013. Pre-existing oblique transfer zones and transfer/transform relationships in continental margins: new insights from the southeastern Gulf of Aden, Socotra Island, Yemen. Tectonophysics, 607, 32-50.

Ben-Avraham, Z., Hartnady, C.J.H., Kitchin, K.A., 1997. Structure and tectonics of the AgulhasFalkland fracture zone. Tectonophysics, 282, 83-98.

Bigot-Cormier, F., Basile, C., Poupeau, G., Bouillin, J.P., Labrin, E., 2005. Denudation of the Côte d'Ivoire-Ghana transform continental margin from apatite fission tracks. Terra Nova, 17 , 2, 189-195. Doi 10.1111/j.13653121.2005.00605.x

Bird, D., 2001. Shear margins: continent-ocean transform and fracture zone boundaries. The Leading Edge, 20, 2, 150-159.

Bird, P., 2003. An updated digital model of plate boundaries. Geochemistry Geophysics Geosystems, 4, 3, 52p. doi: 10.1029/2001GC000252.

Bischoff, J.L., Henyey, T.L., 1974. Tectonic elements of the central part of the Gulf of California. Geol. Soc. Am. Bull., 85, 18931904.

Blarez, E., Mascle, J., 1988. Shallow structures and evolution of the Ivory Coast and Ghana transform margin. Mar. Pet. Geol., 5, 54-64.

ten Brink, U.S, Hackney, R.I., Bannister, S., Stern, T.A., Makovsky, Y., 1997. Uplift of the Transantarctic mountains and the bedrock beneath the East Antarctic ice sheet. Journal of Geophysical Research, 102, B12, 27603-27621.

Chorowicz, J., 1989. Transfer and transform fault zones in continental rifts: examples in the AfroArabian Rift system. Implications of crust breaking. Journal of African Earth Sciences, 8, 2/3/4, 203-214.

Christie-Blick, N., Biddle, K.T., 1985. Deformation and basin formation along strike-slip faults. In K.T. Biddle and N. Christie-Blick (Editors), Strike-slip deformation, basin formation and sedimentation. N. Soc. Econ. Paleontol. Mineral., Spec. Publ., 37, 1-34.

Dauteuil, O., Brun, J.P., 1996. Deformation partitioning in a slow spreading ridge undergoing oblique extension: Mohns Ridge, Norwegian Sea. Tectonics, 15, 4, 870-884.

De Caprona, G.C., 1992. The continental margin of western Côte d'Ivoire: structural framework inherited from intra-continental shearing. $\mathrm{PhD}$ thesis, 150 p., U. Pierre et Marie Curie, Paris.

Delteil, J.R., Valery, P., Montadert, L., Fondeur, C., Patriat, P., Mascle, J., 1974. In: The geology of continental margins. Burk C.A., Drake, C.L. (Eds), Springer, 297-311.
Dingle, R.V., 1973. Post-Palaeozoic stratigraphy of the eastern Agulhas bank, south African continental margin. Marine Geology, 15, 1-23.

Fail, J.P., Montadert, L., Delteil, J.R., Valery, P., Patriat, P., Schlich, R., 1970. Prolongation des zones de fractures de l'océan Atlantique dans le Golfe de Guinée. Earth and Planetary Science Letters, 7, 413-419.

Fitch, T.J., 1972. Plate convergence, transcurrent faults, and internal deformation adjacent to southeast Asia and western Pacific. Journal of Geophysical Research, 77, 23, 4432-4460.

Freund, R., 1974. Kinematics of tranform and transcurrent faults. Tectonophysics, 21, 1-2, 93134.

Gadd, S.A., Scrutton, R.A., 1997. An integrated thermomechanical model for transform continental margin evolution. Geo-Marine Letters, 17, 21-30.

Gerya, T.V., 2012. Origin and model of oceanic transform faults. Tectonophysics, 522-523, 3456.

Gibbs, A.D, 1984. Structural evolution of extensional basin margins. J. Geol. Soc. London, 141, 609-620.

Goff, J.A., Bergman, E.A., Solomon, S.C., 1987. Earthquake source mechanisms and transform fault tectonics in the Gulf of California. Journal of Geophysical Research, 92, B10, 1048510510 .

Huguen, C., Guiraud, M., Benkhelil, J., Mascle, J., 2001. Synlithification deformation processes of the Cretaceous sediments of the Ivory CoastGhana transform margin: a way to detail the margin history. Tectonics, 20, 6, 959-975.

Keen, C.E., Kay, W.A., Roest, W.R., 1990. Crustal anatomy of a transform continental margin. Tectonophysics, 173, 527-544.

Keen, M.J., Keen, C.E., 1973. Subsidence and fracturing on the continental margin of Eastern Canada. In: Earth Science Symposium on offshore Eastern Canada, 1971, P.J. Hood Ed.. Geological Survey Canada Paper 71-23, 23-42.

Le Pichon, X, Hayes, D.E., 1971. Marginal offsets, fracture zones, and the early opening of the South Atlantic. Journal of Geophysical Research, 76, 26, 6283-6293.

Leroy, S., Mauffret, A., Patriat, P., de Lepinay, B.M., 2000. An alternative interpretation of the Cayman trough evolution from a reidentification of magnetic anomalies. Geophysical Journal International, 141, 3, 539557.

Lonsdale, P., 1985. A transform continental margin rich in hydrocarbons, Gulf of California. AAPG Bulletin, 69, 7, 1160-1180.

Lorenzo, J.M., Mutter, J.C., Larson, R.L., Northwest Australia Study Group, 1991. Development of the continent-ocean transform 
boundary of the southern Exmouth Plateau. Geology, 19, 843-846.

Lorenzo, J.M., Vera, E.E., 1992. Thermal uplift and erosion across the continent-ocean transform boundary of the southern Exmouth Plateau. Earth and Planetary Science Letters, 108, 79-92.

Lorenzo, J.M., 1997. Sheared continent-ocean margins: an overview. Geo-Marine Letters, 17, $1-3$.

Lorenzo, J.M., Wessel, P., 1997. Flexure across a continent-ocean fracture zone: the northern Falkland/Malvinas Plateau, South Atlantic. Geo-Marine Letters, 17, 110-118.

Mascle, J., 1976a. Atlantic-type continental margins - Distinction of two basic structural types. Anais da Academia Brasileira de Ciencias, 48, 191-197.

Mascle, J., 1976b. Le golfe de Guinée: exemple d'évolution d'une marge atlantique en cisaillement. Mem. Soc. Geol. Fr., N.S., 128.

Mascle, J., Blarez, E., 1987. Evidence for transform margin evolution from the Ivory Coast Ghana continental margin. Nature, 326, 6111, 378-381.

Mascle, J., Mougenot, D., Blarez, E., Marinho, M., Virlogeux, P., 1987. African transform continental margins: examples from Guinea, the Ivory Coast and Mozambique. Geological Journal, 22, 537-561.

Mascle, J., Lohmann, P., Clift, P.D., Shipboard Scientific Party, 1996. Introduction. In Mascle, J., Lohmann, G.P., Clift, P.D., eds, Proc. ODP Init. Rep., 159, 5-16.

Mascle, J., Lohmann, P., Clift, P.D., ODP 159 Scientific Party, 1997. Development of a passive transform margin: Côte d'Ivoire-Ghana transform margin - ODP Leg 159 preliminary results. Geo-Marine Letters, 17, 4-11.

Mercier de Lepinay, M., Loncke, L., Basile, C., Roest, W.R., de Clarens, P., Maillard, A., Boukandou Sidi, C., Patriat, M. Transform continental margins - part 2: A worldwide inventory. This Volume.

Milani, E.J., Davison, I., 1988. Basement control and transfer tectonics in the Recôncavo-TucanoJatobá rift, Northeast Brazil. Tectonophysics, 154, 41-70.

Moore, D.G., Curray, J.R., 1982. Geologic and tectonic history of the Gulf of California. In Init. Repts. DSDP, 64, 1279-1294.

Nagel, D.K., Mullins, H.T., Geen, H.G., 1986. Ascension submarine canyon, California Evolution of a multi-head canyon system along a strike-slip continental margin. Marine Geology, 73, 3-4, 285-310.

Nemčok, M., Henk, A., Allen, R., Sikora, P.J., Stuart, C., 2012. Continental break-up along strike-slip fault zones; observations from the Equatorial Atlantic. In: Conjugate divergent margins, Mohriak, W.U., Danforth, A., Post, P.J., Brown, D.E., Tari, G.C., Nemčok, M.,
Sinha, S.T. (Eds), Geological Society, London, Special Publications, 369,

Peyve A.A., 2009. Accretion of oceanic crust under conditions of oblique spreading. Geotectonics, 43, 2, 87-99.

Rabinowitz, P.D., Labrecque, J., 1979. Mesozoic South Atlantic ocean and evolution of its continental margins. Journal of Geophysical Research, 84, B11, 5973-6002.

Reid, I., 1989. Effects of lithospheric flow on the formation and evolution of a transform margin. Earth and Planetary Science Letters, 95, 38-52.

Reid, I.D., Jackson, H.R., 1997. A review of three transform margins off eastern Canada. GeoMarine Letters, 17, 87-93.

Rosendahl, B.R., 1987. Architecture of continental rifts with special reference to East-Africa. Annual Review of Earth and Planetary Sciences, 15, 445-503.

Sage, F., Pontoise, B., Mascle, J., Basile, C., Arnould, L., 1997. Crustal structure and oceancontinent transition at marginal ridge: the Côte d'Ivoire-Ghana marginal ridge. Geo-Marine Letters, 17, 40-48.

Sage, F., Basile, C., Mascle, J., Pontoise, B., Whitmarsh, R.B., 2000. Crustal structure of the continent-ocean transition off the Côte d'IvoireGhana transform margin: implications for thermal exchanges across the palaeotransform boundary. Geophys. J. Int. 143, 662-678.

Scrutton, R.A., 1973. Structure and evolution of the sea floor south of South Africa. Earth Planet. Sci. Lett., 19, 250-256.

Scrutton, R.A., 1976. Crustal structure at the continental margin south of South Africa. Geophys. J. R. astr. Soc., 44, 601-623.

Scrutton, R.A., 1979. On sheared passive continental margins. Tectonophysics, 59, 293305.

Scrutton, R.A., 1982. Crustal structure of sheared passive continental margins. Geodynamic Series - Dynamics of passive margins, 6, 133-139.

Sibuet, J.C., Mascle, J., 1978. Plate kinematic implications of Atlantic equatorial fracture zone trends. J. Geophys. Res., 83, NB7, 3401-3421.

Scrutton, R.A., 1979. Sheared passive continental margins. Tectonophysics, 59, 1-4, 293-305.

Taylor, B., Goodliffe, A., Martinez, F., 2009. Initiation of transform faults at rifted continental margins. Comptes Rendus Geoscience, 341, 428-438.

Todd, B.J., Reid, I., Keen, C.E., 1988. Crustal structure across the Southwest Newfoundland transform margin. Can. J. Earth Sci., 25, 744759.

Todd, B.J., Keen, C.E., 1989. Temperature effects and their geological consequences at transform margins. Can. J. Earth Sci., 26, 2591-2603.

Vågnes E., 1997. Uplift at thermo-mechanically coupled ocean-continent transforms: modelled 
at the Senja Fracture Zone, southwestern Barents Sea. Geo-Marine Letters, 17, 100-109.

Versfelt, J., Rosendahl, B.R., 1989. Relationships between pre-rift structure and rift architecture in lakes Tanganyika and Malawi, East Africa. Nature, 337, 6205, 354-357.

Wagner, T., Pletsch, T., 2001. No major thermal event on the mid-Cretaceous Côte d'Ivoire-
Ghana transform margin. Terra Nova, 13, 165171.

Wilson, J.T., 1965. A new class of faults and their bearing on continental drift. Nature, 207, 4995, 343-347.

Wright, J.B., 1976. Fracture systems in Nigeria and initiation of fracture zones in the South Atlantic. Tectonophysics, 34, T43-T47. 